\title{
Effects of supplementation with 2-hydroxy-4-(methylthio)-butanoic acid isopropyl ester on splanchnic amino acid metabolism and essential amino acid mobilization in postpartum transition Holstein cows
}

\author{
K. F. Dalbach, M. Larsen, ${ }^{1}$ B. M. L. Raun, and N. B. Kristensen \\ Department of Animal Science, Faculty of Science and Technology, Aarhus University, Foulum, DK-8830 Tjele, Denmark
}

\begin{abstract}
The present study aimed to investigate the effects of 2-hydroxy-4-(methylthio)-butanoic acid isopropyl ester (HMBi) supplementation on splanchnic AA metabolism, essential AA (EAA) mobilization, and plasma AA status in postpartum transition dairy cows. The EAA mobilization was calculated by difference: EAA excretion in milk protein - net portal absorption of EAA or net splanchnic release of EAA. Eight Holstein cows fitted with permanent indwelling catheters in the hepatic portal vein, hepatic vein, mesenteric vein, and an artery in the dry period preceding second parturition were used in the study. Cows were randomly allocated to 1 of 4 treatments in a $2 \times 2$ factorial arrangement with factor 1: control (calcium carbonate) versus HMBi $[1.5 \mathrm{~g}$ of $\mathrm{HMBi} / \mathrm{kg}$ of dry matter (DM)] and factor 2: high dietary ethanol $(19 \mathrm{~g} / \mathrm{kg}$ of $\mathrm{DM})$ versus high dietary propanol $(16 \mathrm{~g} / \mathrm{kg}$ of $\mathrm{DM})$. Only factor 1 data are presented. Treatments were administered in 4 total mixed rations and initiated on the day of parturition. Cows were sampled $14 \mathrm{~d}$ before expected parturition and 4, 15, and $29 \mathrm{~d}$ after parturition. Supplementation with HMBi tended to increase milk fat content but not fat yield, tended to impose a slower rate of decrease in milk casein content with increasing days in milk (DIM), prevented the decrease in plasma Met associated with parturition for control, reduced plasma concentration of Ser, tended to reduce plasma concentrations of Gly and His, and tended to increase hepatic uptake of Met postpartum. Cows excreted $248 \pm 18$ $\mathrm{g}$ more EAA in the milk at 4 DIM than was released from splanchnic tissues. The EAA deficiency decreased as lactation progressed and was not affected by $\mathrm{HMBi}$ supplementation. It was estimated that $4,700 \pm 600 \mathrm{~g}$ of EAA from extra-splanchnic tissues were secreted in milk protein during the first 29 DIM. Extra-splanchnic EAA mobilization can be crucial to sustain milk protein
\end{abstract}

Received August 16, 2010.

Accepted April 6, 2011.

${ }^{1}$ Corresponding author: Mogens.Larsen@agrsci.dk yield in the postpartum transition period and HMBi is a fast-working Met source that can improve Met status of postpartum transition cows.

Key words: transition dairy cow, amino acid, metabolism, methionine hydroxy analog

\section{INTRODUCTION}

The immediate metabolic adaptation to milk secretion in postpartum transition dairy cows induces mobilization of nutrients deposited in body tissue (Gibb et al., 1992; Andrew et al., 1994). The increased susceptibility for metabolic disorders also characterizing the transition period (Grummer, 1995) has led to extensive studies of the links between excessive lipid mobilization and metabolic diseases (Drackley, 1999). A connection between negative protein balance and reduced health and longevity of cows has likewise been speculated (Bell et al., 2000), but the protein metabolism of the transition cow is rarely investigated. The homeorhetic adaptations associated with lactogenesis involve repartitioning of AA to sustain increased demands of the mammary gland. It has previously been speculated that the essential AA (EAA) excreted in milk protein in excess of the dietary supply during the postpartum transition period were partly of splanchnic origin (Bell et al., 2000). Contrary to this assumption, Larsen and Kristensen (2009) observed that the output of EAA in milk protein was twice the splanchnic EAA release, indicating that peripheral tissues contributed substantially to EAA secretion in milk postpartum. Data on splanchnic EAA fluxes hereby supported estimates based on other techniques in that mobilization of AA can be of fundamental importance for meeting the mammary demand for EAA in the first week of lactation (Komaragiri and Erdman, 1997; Phillips et al., 2003). For that reason, milk protein production as well as several nonmammary functions of AA (immune system, AA-derived regulatory compounds, methyl donation reactions, and protein turnover) might be negatively affected by the shortage of EAA in very early lactation. 
Increasing the supply of metabolizable Met by feeding rumen-protected Met (Berthiaume et al., 2006) or supplying a Met analog [2-hydroxy-4-(methylthio)butanoic acid isopropyl ester, HMBi; St-Pierre and Sylvester, 2005; Ordway et al., 2009] have repeatedly been shown to increase milk protein content and yield. This indicates an effect of Met on the postabsorptive metabolism of other AA and on their efficiency of incorporation into milk protein. Methionine is also a key intermediate for methyl group transfer and is involved in numerous pathways (Lobley et al., 1996), including phospholipid synthesis, which might be part of the explanation for the observed increase in milk fat production following HMBi supplementation in some studies (e.g., St-Pierre and Sylvester, 2005). Our hypothesis was that supplementation of postpartum transition cows with HMBi would increase the supply of Met to peripheral tissues and potentially alleviate negative consequences of low postpartum Met status on nutrient allocation to milk production. Therefore, the objectives of the study were to investigate effects of postpartum HMBi supplementation on splanchnic AA metabolism in the postpartum transition dairy cow. In addition, we aimed to determine the composition of milk protein to assess whether extra mammary synthesized proteins accounted for a large fraction of EAA in milk not accounted for by splanchnic AA output.

\section{MATERIALS AND METHODS}

The present experiment complied with Danish Ministry of justice Law No. 382 (June 10, 1987), Act No. 726 (September 9, 1993) concerning experiments with animals and care of experimental animals.

\section{Animals and Housing}

Eight Danish Holstein cows entering their second lactation were used in the study. Six weeks before expected parturition, cows were surgically prepared with ruminal cannulas and permanent indwelling catheters in the mesenteric vein, hepatic portal vein, hepatic vein, and an artery (Kristensen et al., 2007). The cows were housed in tie stalls with rubber mats, and wood shavings were used as bedding. Cows were milked at 0530 and $1530 \mathrm{~h}$.

\section{Experimental Design and Treatments}

The experimental design was a complete randomized design with repeated measurements and 4 treatments in a $2 \times 2$ factorial arrangement. Factor 1 was control (calcium carbonate) versus HMBi $(1.5 \mathrm{~g} / \mathrm{kg}$ of DM as $2.6 \mathrm{~g}$ of MetaSmart $/ \mathrm{kg}$ of DM; Table 1) and factor
2 was high dietary ethanol $(19 \mathrm{~g} / \mathrm{kg}$ of $\mathrm{DM})$ versus high dietary propanol $(16 \mathrm{~g} / \mathrm{kg}$ of $\mathrm{DM})$. Only factor 1 data are presented. Treatments were administered by 4 different TMR. Treatments were initiated on the day of calving, assigned as +1 DIM. Prepartum, all cows were offered the same nonlactation ration (Table 1). The feed allowance during the dry period was restricted to $10 \mathrm{~kg}$ of $\mathrm{DM} / \mathrm{d}$. Postpartum, diets were offered ad libitum ( $10 \%$ orts). The daily ration was divided in 3 equivalent meals, fed at 0800, 1600, and $2400 \mathrm{~h}$, and orts removed at $0730 \mathrm{~h}$. Each treatment TMR was mixed in one single mix, bagged in portions of 15 to $20 \mathrm{~kg}$ within 2 to $3 \mathrm{~h}$ after mixing, and evacuated using a chamber vacuum packaging machine (Webomatic I22, Webo A/S, Årup, Denmark). The vacuum-packed TMR was initially frozen at -20 to $-25^{\circ} \mathrm{C}$ and kept at $-6^{\circ} \mathrm{C}$ during the study period. Feed was allowed to thaw overnight on the barn floor.

\section{Experimental Samplings}

Cows were sampled once prepartum at $\mathrm{d}-15 \pm 2$ relative to parturition and sampled postpartum on 4 , 15, and 29 DIM. Splanchnic blood plasma flows were measured by downstream dilution of $p$-aminohippuric acid (pAH; $175 \mathrm{mmol} / \mathrm{L}$ sterile solution at $\mathrm{pH} 7.4$ ) infused continuously into the mesenteric vein at 27.4 $\pm 1.6 \mathrm{mmol} / \mathrm{h}$, initiated $1 \mathrm{~h}$ before the first sampling.

First blood sampling was $30 \mathrm{~min}$ before feeding at $0800 \mathrm{~h}$, and a total of 8 hourly sample sets were collected from the artery, portal vein, and hepatic vein. Thirty milliliters of blood was simultaneously collected from each catheter at each sampling time and blood was immediately transferred to heparin vacuettes (Greiner BioOne GmbH, Frickenhausen, Austria). Blood samples were immediately placed on ice and plasma was harvested after centrifugation at $3,000 \times$ $g$ for 20 min at $4^{\circ} \mathrm{C}$. Plasma was stored at $-20^{\circ} \mathrm{C}$ until analysis. Milk yield and feed intake were recorded daily, and milk samples for analysis of milk composition were collected on sampling days. Nine randomly selected vacuum bags from each TMR were collected for feed analysis. Cows were weighed before the afternoon milking on each sampling day.

\section{Chemical Analyses}

To correct for the acetylation of pAH occurring in the liver (Kristensen et al., 2009), all plasma samples were deacetylated before analysis by combining plasma with an equal volume of $20 \% \mathrm{TCA}$, and then incubated at $100^{\circ} \mathrm{C}$ for $1 \mathrm{~h}$. Subsequently, pAH concentrations were determined according to Harvey and Brothers (1962) using a continuous flow analyzer (method US-216-72 
Table 1. Ingredients and nutrient composition of nonlactation and lactation (control and HMBi) TMR (g/kg of DM unless otherwise noted)

\begin{tabular}{|c|c|c|c|}
\hline \multirow[b]{2}{*}{ Item } & \multirow[b]{2}{*}{ Nonlactation } & \multicolumn{2}{|c|}{ Lactation } \\
\hline & & Control & $\mathrm{HMBi}$ \\
\hline \multicolumn{4}{|l|}{ Ingredient } \\
\hline Corn silage $^{1}$ & 450 & 400 & 400 \\
\hline Grass clover silage $^{2}$ & 200 & 250 & 250 \\
\hline Barley straw, chopped & 118 & - & - \\
\hline Wheat grain, rolled & 75 & - & - \\
\hline Whole wheat grain, $\mathrm{NaOH}$ treated & & 207 & 207 \\
\hline Soybean meal, $47 \% \mathrm{CP}$ & 100 & 100 & 100 \\
\hline Molasses, sugar beet & 10 & 17.2 & 17.2 \\
\hline Sugar beet pulp & 24 & - & - \\
\hline Mineral and vitamin premixes & $13^{3}$ & $6^{4}$ & $6^{4}$ \\
\hline Vitamin E premix ${ }^{5}$ & - & 1 & 1 \\
\hline Vegetable fat ${ }^{6}$ & 7.5 & 10 & 10 \\
\hline Feed-grade urea & - & 2.5 & 2.5 \\
\hline $\mathrm{NaCl}$ & 2.5 & - & - \\
\hline MetaSmart, dry $^{7}$ & - & - & 2.6 \\
\hline $\mathrm{CaCO}_{3}$ & - & 5.2 & 2.6 \\
\hline Chromium(III)oxide & - & 1 & 1 \\
\hline \multicolumn{4}{|l|}{ Nutrient } \\
\hline $\mathrm{DM}(\mathrm{g} / \mathrm{kg})$ & 478 & 411 & 405 \\
\hline Ash & 57 & 62 & 63 \\
\hline Crude fat & 36 & 36 & 36 \\
\hline NDF & 358 & 273 & 270 \\
\hline $\mathrm{CP}$ & 144 & 155 & 155 \\
\hline Starch (calculated) & 203 & 277 & 277 \\
\hline $\mathrm{MP}^{8}$ & 72 & 89 & 90 \\
\hline Metabolizable $\mathrm{Met}^{8}$ (\% of MP) & 2.23 & 2.17 & 2.99 \\
\hline Metabolizable Lys ${ }^{8}$ ( $\%$ of MP) & 7.01 & 6.68 & 6.67 \\
\hline $\mathrm{NE}_{\mathrm{L}}^{8}(\mathrm{MJ} / \mathrm{kg}$ of $\mathrm{DM})$ & 6.84 & 6.99 & 7.01 \\
\hline
\end{tabular}

${ }^{1}$ Chemical composition of corn silage: DM, 363 (g/kg); ash, 31; CP, 87; NDF, 375; starch, 320; in vitro OM digestibility, $72.5 \%$

${ }^{2}$ Chemical composition of grass clover silage: DM, 407 (g/kg); ash, 86; CP, 146; NDF, 363; in vitro OM digestibility, $78.8 \%$.

${ }^{3}$ Premix dry (Gold alfa Bio org Selen, Vitfoss, Gråsten, Denmark) containing 2\% Ca, 4\% P, 19.2\% Mg, $3.6 \%$ $\mathrm{Na}, 8.3 \% \mathrm{~S}, 18,182 \mathrm{mg} / \mathrm{kg}$ of vitamin E, $91 \mathrm{mg} / \mathrm{kg}$ of biotin, 3,636 mg/ $\mathrm{kg}$ of Mn, $909 \mathrm{mg} / \mathrm{kg}$ of $\mathrm{Cu}, 36 \mathrm{mg} / \mathrm{kg}$ of Co, $6,364 \mathrm{mg} / \mathrm{kg}$ of $\mathrm{Zn}, 227 \mathrm{mg} / \mathrm{kg}$ of I, $24 \mathrm{mg} / \mathrm{kg}$ of Se.

${ }^{4}$ Premix lactation (VM2, Vitfoss) containing $16 \% \mathrm{Ca}, 5 \% \mathrm{P}, 6.5 \% \mathrm{Mg}, 9 \% \mathrm{Na}, 0.5 \% \mathrm{~S}, 600 \mathrm{IU} / \mathrm{g}$ of vitamin A, $190 \mathrm{IU} / \mathrm{g}$ of vitamin $\mathrm{D}_{3}, 4,000 \mathrm{IU} / \mathrm{g}$ of vitamin $\mathrm{E}, 4,000 \mathrm{mg} / \mathrm{kg}$ of $\mathrm{Mn}, 1,500 \mathrm{mg} / \mathrm{kg}$ of Cu, $25 \mathrm{mg} / \mathrm{kg}$ of Co, $4,500 \mathrm{mg} / \mathrm{kg}$ of $\mathrm{Zn}, 225 \mathrm{mg} / \mathrm{kg}$ of $\mathrm{I}, 50 \mathrm{mg} / \mathrm{kg}$ of Se.

${ }^{5}$ Suplex D-alfa E-50000 (Vitfoss) containing $33.557 \mathrm{mg} / \mathrm{kg}$ of $\alpha$-tocopherol.

${ }^{6}$ Palm fatty acid distillate (Scanfedt A/S, Fredericia, Denmark).

${ }^{7}$ 2-Hydroxy-4-(methylthio)-butanoic acid isopropyl ester (HMBi; MetaSmart, Adisseo, Antony, France).

${ }^{8}$ Calculated at DMI levels of $10 \mathrm{~kg}$ of DMI/d prepartum and $20 \mathrm{~kg}$ of DMI/d postpartum using the nonadditive Norfor feed evaluation system (Volden, 2011).

Rev.1; Autoanalyzer 3, Seal Analytic Ltd., Burgess Hill, UK).

All laboratory analyses other than pAH analysis were conducted on samples pooled within cow and sampling day. Heparinized plasma samples were analyzed for AA by GC-MS according to the isotope dilution method described by Calder et al. (1999). A working AA standard was prepared from a commercial AA mixture (AAS18; Sigma-Aldrich Denmark A/S, Brøndby, Denmark) with added glutamine (L-glutamine 99\%, final concentration $400 \mu M$; Acros, Geel, Belgium). The internal standard was made from a $\left[\mathrm{U}_{-}^{13} \mathrm{C} / \mathrm{U}_{-}{ }^{15} \mathrm{~N}\right]$ cell-free AA mixture (CNLM-6696-1; Cambridge Isotope Laboratories Inc.,
Andover, MA) with added $\left[{ }^{15} \mathrm{~N}_{2}\right]$ urea (no. 316830; Campro Scientific GmbH, Berlin, Germany). Essential AA analyzed were His, Ile, Leu, Lys, Met, Phe, Thr, Trp, and Val; and non-EAA analyzed were Ala, Asn, Asp, Cys, Gln, Glu, Gly, Pro, Ser, and Tyr. Total protein determination was performed using the biuret reaction endpoint method (ABX Pentra Total Protein CP; Horiba ABX, Montpellier, France) adapted for use on a Cobas Mira autoanalyzer. Milk samples were analyzed for fat, protein, and lactose by infrared spectroscopy with a MilkoScan 4000 (Foss Electric, Hillerød, Denmark) at a commercial laboratory (Eurofins Steins A/S, Holstebro, Denmark). 


\section{Milk Fractionation}

Milk samples from morning and afternoon milking were pooled according to milk yield, and the pooled samples were skimmed by centrifugation at $3,500 \times g$ for $20 \mathrm{~min}$ at $5^{\circ} \mathrm{C}$. The skim milk was separated into noncasein nitrogen (NCN) and NPN. The NCN fraction was prepared by adjusting the $\mathrm{pH}$ of the skim milk to 4.6 using $10 \%$ acetic acid to precipitate the caseins and centrifuged at $1,000 \times g$ for $10 \mathrm{~min}$ at $5^{\circ} \mathrm{C}$. The casein was washed 2 times with water, followed by centrifugation at $1,000 \times g$ for $5 \mathrm{~min}$ at $5^{\circ} \mathrm{C}$, and finally dissolved in $0.1 M$ citrate. The NPN fraction was prepared by adding $15 \%$ TCA to skim milk $(4+1$; vol/ vol) to precipitate all proteins, followed by centrifugation at $1,000 \times \mathrm{g}$ for $10 \mathrm{~min}$ at $5^{\circ} \mathrm{C}$; the supernatant contained the NPN fraction.

Nitrogen determination was performed on skim milk (determination of total $\mathrm{N}$ content) and on the $\mathrm{NCN}$ and NPN fractions. The skim milk and NCN were weighed into tinfoil capsules, 12.5 and $50 \mu \mathrm{L}$, respectively. Twenty-five microliters of NPN was weighed into silver cups and the exact weight was recorded. The samples were dried at $100^{\circ} \mathrm{C}$ for $30 \mathrm{~min}$ and the $\mathrm{N}$ content determined according to the Dumas principle by using an elemental analyzer (Flash EA, Thermo Scientific, Copenhagen, Denmark).

\section{Calculations and Statistics}

One cow (HMBi treatment) had retained placenta and her data from 4 DIM were removed from the data set. None of the other cows were affected by diseases during the study and all catheters remained functional throughout the study.

The net fluxes $(\mathrm{mmol} / \mathrm{h})$ were calculated as the products of plasma flow $(\mathrm{L} / \mathrm{h})$ and venous-arterial concentration differences $(\mathrm{mmol} / \mathrm{L})$ for the portaldrained viscera (PDV), liver, and the splanchnic bed as described previously (Kristensen et al., 2007). Positive fluxes indicate a net release of a metabolite and negative fluxes indicates a net uptake of a metabolite.

The EAA output in milk protein was calculated using the milk protein yield and tabulated values for EAA composition of milk (g/ $/ \mathrm{kg}$ of protein): His: 27; Ile: 59; Leu: 98; Lys: 83; Met: 28; Phe: 49; Thr: 43; Trp: 15; Val: 66 (Swaisgood, 1995). The EAA balance was calculated as the difference between milk protein EAA yield/d and splanchnic or PDV net fluxes of EAA/d. The total EAA deficiency was calculated as the mean EAA balance weighed by the time period represented by each sampling (i.e., DIM $4=0.31$; DIM $15=0.45$; DIM $29=0.24)$.
The true protein content in milk was determined as the difference between total N and NPN. Casein N content was calculated as the difference between total $\mathrm{N}$ and NCN. Whey protein content was calculated as the difference between NCN and NPN. The N content was multiplied by 6.38 to obtain the milk protein content (DePeters and Cant, 1992).

Data were analyzed as a complete randomized design, where cow was considered as a random factor and DIM was considered as repeated measures, analyzed using an autoregressive order 1 covariance structure. The MIXED procedure in SAS (version 9.1, SAS Institute Inc., Cary, NC) was used. Metabolite concentrations, net flux data, DMI, BW, and milk variables were analyzed using a model including the fixed effects of factor 1 (2 levels), factor 2 (2 levels), DIM (3 levels), and the possible interactions. Statistics in Tables 2 to 6 for effects of treatment, DIM, and treatment $\times$ DIM were computed using a data set containing only postpartum data. Differences between treatment means within DIM were separated using Fisher's protected least significant difference test. To test whether treatment affected the difference between prepartum and 4 DIM (named $P_{\text {trans } \times \text { trt }}$ in tables), data including the prepartum observations and the model described above were used for computing Fisher's least significant difference test. Fisher's least significant difference test was also used to test for an overall difference between prepartum and 4 DIM values (named $P_{\text {trans }}$ in tables). Data are presented as least squares means \pm residual standard error of the means. Significance was declared at $P \leq 0.05$ and tendencies were considered at $0.05<P \leq 0.10$.

\section{RESULTS}

\section{Feed Intake, Milk Yield, and Milk Composition}

Dry matter intake increased from d 15 prepartum to 4 DIM $(P<0.01$; Table 2$)$ and continued to increase $(P$ $<0.01)$ postpartum without being affected $(P=0.30)$ by HMBi supplementation. A tendency was observed toward a treatment $\times$ DIM interaction for milk yield $(P=0.10)$, which reflected a lower rate of increase in HMBi compared with control. A tendency $(P=0.08)$ was found for a treatment $\times$ DIM interaction for milk protein content, reflecting a more rapid decrease from 4 to 15 DIM in control compared with HMBi. Milk fat and lactose yield increased $(P=0.05$ and $P<0.01)$ as lactation progressed. Milk fat content tended to be greater for HMBi $(P=0.07)$ compared with control and decreased $(P=0.02)$ for both groups as lactation progressed. A tendency $(P=0.06)$ was observed for an interaction between treatment and DIM for casein con- 
Table 2. Dry matter intake, BW, milk yield, milk composition, and milk protein fractions in periparturient Holstein cows supplemented with 2-hydroxy-4-(methylthio)-butanoic acid isopropyl ester (HMBi; $1.5 \mathrm{~g} / \mathrm{kg}$ of $\mathrm{DM})$ or not supplemented $(\mathrm{CON})$ from the day of parturition

\begin{tabular}{|c|c|c|c|c|c|c|c|c|c|c|c|c|c|c|}
\hline \multirow[b]{2}{*}{ Item } & \multicolumn{2}{|c|}{ Prepartum } & \multirow[b]{2}{*}{$P_{\text {trans } \times \text { trt }}^{1}$} & \multirow[b]{2}{*}{$P_{\text {trans }}^{2}$} & \multicolumn{2}{|c|}{$4 \mathrm{DIM}$} & \multicolumn{2}{|c|}{15 DIM } & \multicolumn{2}{|c|}{29 DIM } & \multirow[b]{2}{*}{$\mathrm{SEM}^{3}$} & \multicolumn{3}{|c|}{$P$-value ${ }^{4}$} \\
\hline & $\mathrm{CON}$ & HMBi & & & $\mathrm{CON}$ & $\mathrm{HMBi}$ & $\mathrm{CON}$ & $\mathrm{HMBi}$ & $\mathrm{CON}$ & $\mathrm{HMBi}$ & & Trt & DIM & Trt $\times$ DIM \\
\hline DMI (kg/d) & 10 & 10 & 0.77 & $<0.01$ & 14 & 15 & 17 & 18 & 20 & 20 & 0.44 & 0.30 & $<0.01$ & 0.59 \\
\hline Weight (kg) & 637 & 639 & 0.20 & $<0.01$ & 604 & 625 & 581 & 575 & 581 & 579 & 16.9 & 0.96 & $<0.01$ & 0.14 \\
\hline \multicolumn{15}{|l|}{ Yield (kg/d) } \\
\hline Milk & & & & & 27.6 & 27.6 & 35.6 & 32.7 & 40.1 & 35.8 & 2.47 & 0.52 & $<0.01$ & 0.10 \\
\hline $\mathrm{ECM}^{5}$ & & & & & 31.0 & 33.6 & 34.5 & 34.6 & 37.7 & 36.6 & 1.85 & 0.90 & 0.01 & 0.36 \\
\hline Milk fat & & & & & 1.26 & 1.51 & 1.38 & 1.44 & 1.51 & 1.58 & 0.08 & 0.26 & 0.05 & 0.31 \\
\hline Milk protein & & & & & 1.19 & 1.21 & 1.12 & 1.12 & 1.18 & 1.07 & 0.05 & 0.60 & 0.22 & 0.38 \\
\hline \multirow{2}{*}{\multicolumn{15}{|c|}{ Milk composition $(\mathrm{g} / \mathrm{kg})$}} \\
\hline & & & & & & & & & & & & & & \\
\hline Fat & & & & & 45 & 51 & 39 & 44 & 38 & 48 & 2.0 & 0.07 & 0.02 & 0.87 \\
\hline Protein & & & & & 43 & 41 & 32 & 34 & 29 & 30 & 0.9 & 0.60 & $<0.01$ & 0.08 \\
\hline Lactose $^{6}$ & & & & & 46 & 45 & 49 & 50 & 49 & 49 & 0.06 & 0.38 & $<0.01$ & 0.47 \\
\hline \multicolumn{15}{|c|}{ Protein composition $(\mathrm{g} / \mathrm{kg})$} \\
\hline True protein & & & & & 46 & 42 & 32 & 34 & 29 & 31 & 1.60 & 0.99 & $<0.01$ & 0.10 \\
\hline Casein & & & & & 37 & 36 & 25 & 28 & 23 & 24 & 1.30 & 0.69 & $<0.01$ & 0.06 \\
\hline Whey & & & & & 7.8 & 7.0 & 5.2 & 5.1 & 4.8 & 5.5 & 0.60 & 0.82 & 0.01 & 0.65 \\
\hline NPN & & & & & 1.2 & 1.4 & 1.1 & 1.2 & 1.3 & 1.1 & 0.10 & 0.89 & 0.65 & 0.54 \\
\hline
\end{tabular}

${ }^{1}$ Fisher's LSD test for treatment effect on difference between prepartum and 4 DIM

${ }^{2}$ Fisher's LSD test for prepartum to differ from 4 DIM.

¿. $\quad{ }^{3}$ Standard error of the mean $(\mathrm{n}=4$; except for 4 DIM HMBi where $\mathrm{n}=3)$.

${ }^{4}$ Fixed effects when prepartum observations are excluded from data set.

$\stackrel{{ }^{5}}{0}$ Calculated according to Sjaunja et al. (1991)

음 ${ }^{6}$ Lactose monohydrate. 
tent in milk, which reflected a more rapid decline from 4 to 15 DIM for control compared with HMBi. The whey protein content decreased $(P<0.01)$ from 4 to 29 DIM and was not affected by treatment $(P=0.82)$.

\section{Arterial Variables}

The arterial concentration of total EAA decreased $(P<0.01$; Table 3$)$ from prepartum to 4 DIM and this effect was apparent for most individual EAA except for Met, Thr, and Trp. Postpartum, total EAA tended to increase with DIM, which was especially apparent for Thr and $\operatorname{Trp}(P=0.04$ and $P=0.01)$. A transition $\times$ treatment effect $(P=0.01)$ was observed for arterial Met, reflecting an increase in the concentration from prepartum to 4 DIM in HMBi compared with a decrease in control. Arterial Met tended to be higher in HMBi compared with control postpartum $(P=0.09)$ and although no interaction between treatment and DIM was detected, the effect appeared smaller on 15 and 29 DIM compared with 4 DIM. Supplementation with HMBi affected arterial His from prepartum to 4 DIM $(P=0.04)$, resulting in a greater decrease for HMBi compared with control. The reduced arterial concentration of His at 4 DIM with HMBi tended $(P=$ 0.10) to persist through 29 DIM.

Contrary to that of EAA, the arterial concentration of non-EAA increased $(P<0.01)$ from prepartum to 4 DIM. This increase was particularly mediated by increased $(P<0.01)$ arterial concentrations of Gly and Ser. Postpartum, higher concentrations of Gln $(P$ $=0.02)$ and Glu $(P=0.05)$ were observed for HMBi compared with control, particularly on 15 and 29 DIM. Conversely, HMBi supplementation decreased $(P<$ 0.01 ) the arterial concentration of Ser compared with control. Glycine concentrations tended to be affected by treatment $\times \operatorname{DIM}(P=0.07)$, reflecting a decreased Gly concentration in HMBi compared with control, especially at 15 DIM. The arterial concentration of total plasma protein decreased $(P<0.01)$ from prepartum to 4 DIM. By 29 DIM, the protein concentration of both treatments had reached prepartum concentrations.

\section{Blood Flows}

The portal and hepatic blood plasma flows increased $(P<0.01$ to $P=0.02$; Table 3$)$ from prepartum to 4 DIM, but were not affected by treatment $(P=0.24$ to $P=0.73)$. Postpartum, portal and hepatic blood plasma flows increased $(P=0.01)$ from 4 to 29 DIM and were not affected by treatment.

\section{Net Portal Fluxes}

The net portal fluxes for all AA increased $(P<$ 0.01 to $P=0.06$ ) from prepartum to 4 DIM except for His $(P=0.17)$, Cys $(P=0.45)$, and Gln $(P=$ $0.89)$. Treatment did not affect $(P=0.24$ to $P=0.99)$ the prepartum to 4 DIM differences for any of the net portal fluxes of AA (Table 4). Postpartum, none of the individual EAA were affected by treatment but increased $(P<0.01$ to $P=0.04)$ with increasing DIM for both treatments except for His and Trp, where no changes in net portal fluxes were detected $(P=0.20$ and $P=0.21$ ). Postpartum, Ala had the greatest net portal flux followed by Gly, Leu, and Ser. The net portal flux of total non-EAA was less $(P=0.03)$ for HMBi compared with control, but increased $(P=0.02)$ from 4 to 29 DIM for both treatments. The net portal flux of Gln differed from that of other AA by being negative both pre- and postpartum, and postpartum the net flux of Gln was greater $(P=0.05)$ for control; however, Gln fluxes showed large variation. The net portal flux of Gly was greater $(P<0.01)$ for control compared with HMBi, especially on 15 DIM (control: $45 \mathrm{mmol} / \mathrm{h}$; HMBi: $20 \mathrm{mmol} / \mathrm{h}$ ).

\section{Net Hepatic Fluxes}

For both treatments the net hepatic fluxes of individual EAA and total EAA were generally negative (net uptake) prepartum (Table 5). Apart from Met and Leu, the postpartum net hepatic fluxes of individual EAA were unaffected by treatment $(P=0.25$ to $P=$ 0.95). Postpartum, a tendency $(P=0.08)$ was observed toward a greater net hepatic uptake of Met for HMBi compared with control, and was most pronounced at 4 and 29 DIM. An interaction between treatment and DIM was observed for net hepatic flux of Leu $(P=$ 0.04), reflecting that the hepatic uptake of Leu at 4 DIM with HMBi changed to a net release on 15 and 29 DIM in contrast to the increased net uptake in control from 4 to 15 DIM.

The net hepatic flux of most non-EAA changed from prepartum to 4 DIM, especially the net hepatic uptake of Ala, Asn, Gly, and Ser increased $(P<0.01$ to $P$ $=0.02)$. However, the net hepatic release of Asp and Glu increased $(P<0.01)$ from prepartum to 4 DIM. A tendency $(P=0.08)$ was found for a treatment $\times$ DIM interaction for the net hepatic flux of Ala, reflecting a reduction in net uptake from 4 to 15 DIM for HMBi compared with a more constant net uptake for control as lactation progressed. Glycine and Ser were removed in the greatest quantities by the liver along with Ala, but no treatment effects $(P=0.24$ to $P=0.74)$ were observed for Gly and Ser. The net hepatic removal of Gly decreased $(P=0.04)$ as lactation progressed, but did not reach prepartum values by 29 DIM. Unlike Gly, Ser was taken up in increasing amounts $(P=0.05)$ by the liver from 4 to 29 DIM. Glutamate was released in 
Table 3. Blood plasma flows and arterial concentrations of AA in periparturient Holstein cows supplemented with 2-hydroxy-4-(methylthio)-butanoic acid isopropyl ester (HMBi; $1.5 \mathrm{~g} / \mathrm{kg}$ of $\mathrm{DM})$ or not supplemented $(\mathrm{CON})$ from the day of parturition

\begin{tabular}{|c|c|c|c|c|c|c|c|c|c|c|c|c|c|c|}
\hline \multirow[b]{2}{*}{ Item } & \multicolumn{2}{|c|}{ Prepartum } & \multirow[b]{2}{*}{$P_{\text {trans } \times \text { trt }}^{1}$} & \multirow[b]{2}{*}{$P_{\text {trans }}^{2}$} & \multicolumn{2}{|c|}{4 DIM } & \multicolumn{2}{|c|}{15 DIM } & \multicolumn{2}{|c|}{29 DIM } & \multirow[b]{2}{*}{$\mathrm{SEM}^{3}$} & \multicolumn{3}{|c|}{$P$-value ${ }^{4}$} \\
\hline & $\mathrm{CON}$ & HMBi & & & $\mathrm{CON}$ & HMBi & $\mathrm{CON}$ & HMBi & $\mathrm{CON}$ & $\mathrm{HMBi}$ & & Trt & DIM & Trt $\times$ DIM \\
\hline \multicolumn{15}{|c|}{ Blood plasma flow $(\mathrm{L} / \mathrm{h})$} \\
\hline Portal vein & 692 & 670 & 0.72 & $<0.01$ & 949 & 959 & 1,074 & 1,049 & 1,073 & 1,066 & 57 & 0.73 & 0.01 & 0.87 \\
\hline Hepatic vein & 766 & 763 & 0.73 & $<0.01$ & 1,092 & 1,067 & 1,196 & 1,158 & 1,218 & 1,222 & 44 & 0.60 & 0.01 & 0.71 \\
\hline Hepatic artery & 73 & 93 & 0.24 & 0.02 & 145 & 112 & 121 & 109 & 145 & 156 & 37 & 0.95 & 0.12 & 0.69 \\
\hline \multicolumn{15}{|l|}{ Blood plasma $(\mu \mathrm{mol} / \mathrm{L})$} \\
\hline Essential AA & 753 & 753 & 0.71 & $<0.01$ & 540 & 560 & 626 & 626 & 666 & 629 & 50 & 0.90 & 0.10 & 0.80 \\
\hline Branched-chain AA & 437 & 437 & 0.76 & $<0.01$ & 288 & 299 & 332 & 351 & 344 & 329 & 29 & 0.94 & 0.15 & 0.74 \\
\hline His & 46 & 46 & 0.04 & $<0.01$ & 38 & 17 & 39 & 15 & 37 & 21 & 7 & 0.10 & 0.78 & 0.47 \\
\hline Ile & 115 & 122 & 0.78 & $<0.01$ & 88 & 87 & 102 & 113 & 104 & 98 & 10 & 0.96 & 0.05 & 0.34 \\
\hline Leu & 118 & 119 & 0.96 & $<0.01$ & 70 & 70 & 74 & 78 & 76 & 83 & 6 & 0.61 & 0.29 & 0.82 \\
\hline Lys & 81 & 76 & 0.61 & $<0.01$ & 51 & 52 & 60 & 65 & 60 & 64 & 5 & 0.59 & 0.08 & 0.85 \\
\hline Met & 21 & 20 & 0.01 & 0.79 & 17 & $23^{*}$ & 17 & 22 & 18 & 19 & 1 & 0.09 & 0.41 & 0.18 \\
\hline Phe & 47 & 49 & 0.36 & $<0.01$ & 36 & 41 & 39 & 38 & 41 & 41 & 3 & 0.75 & 0.45 & 0.46 \\
\hline Thr & 87 & 93 & 0.44 & 0.87 & 82 & 100 & 100 & 101 & 125 & 115 & 10 & 0.82 & 0.04 & 0.47 \\
\hline Trp & 35 & 32 & 0.21 & 0.25 & 28 & 32 & 39 & 35 & 41 & 40 & 3 & 0.89 & 0.01 & 0.37 \\
\hline Val & 199 & 196 & 0.44 & $<0.01$ & 131 & 141 & 156 & 160 & 164 & 149 & 14 & 0.92 & 0.20 & 0.61 \\
\hline Nonessential AA & 1,064 & 1,123 & 0.69 & $<0.01$ & 1,354 & 1,384 & 1,467 & 1,399 & 1,355 & 1,388 & 31 & 0.85 & 0.11 & 0.24 \\
\hline Ala & 164 & 196 & 0.76 & 0.04 & 144 & 161 & 194 & 185 & 201 & 209 & 10 & 0.74 & $<0.01$ & 0.11 \\
\hline Asn & 29 & 32 & 0.94 & 0.16 & 32 & 34 & 43 & 43 & 48 & 47 & 3 & 0.83 & $<0.01$ & 0.87 \\
\hline Asp & 8 & 7 & 0.10 & $<0.01$ & 4 & 4 & 7 & 5 & 7 & 6 & 0.6 & 0.29 & $<0.01$ & 0.22 \\
\hline Cys & 111 & 110 & 0.67 & $<0.01$ & 73 & 74 & 97 & 100 & 102 & 95 & 3 & 0.88 & $<0.01$ & 0.22 \\
\hline Gln & 294 & 321 & 0.80 & 0.38 & 321 & 335 & 265 & $344^{*}$ & 246 & $358^{* *}$ & 24 & 0.02 & 0.38 & 0.20 \\
\hline Glu & 75 & 78 & 0.94 & $<0.01$ & 63 & 65 & 63 & 69 & 62 & $73^{* *}$ & 2 & 0.05 & 0.38 & 0.18 \\
\hline Gly & 204 & 199 & 0.69 & $<0.01$ & 491 & 466 & 524 & $429^{*}$ & 416 & 368 & 25 & 0.14 & $<0.01$ & 0.07 \\
\hline Pro & 59 & 65 & 0.40 & 0.21 & 61 & 71 & 82 & 81 & 85 & 78 & 4 & 0.10 & $<0.01$ & 0.09 \\
\hline Ser & 73 & 72 & 0.40 & $<0.01$ & 140 & 126 & 157 & $105^{* *}$ & 142 & $105^{*}$ & 7 & $<0.01$ & 0.84 & 0.12 \\
\hline Tyr & 45 & 44 & 0.29 & $<0.01$ & 26 & 30 & 36 & 38 & 45 & 42 & 3 & 0.78 & $<0.01$ & 0.41 \\
\hline Total AA & 1,811 & 1,876 & 0.97 & 0.16 & 1,894 & 1,936 & 2,093 & 2,025 & 2,024 & 2,017 & 57 & 0.81 & 0.04 & 0.50 \\
\hline Total protein (g/L) & 83 & 78 & 0.60 & $<0.01$ & 73 & 71 & 79 & 75 & 81 & 81 & 1.95 & 0.36 & 0.01 & 0.50 \\
\hline \\
\hline \multicolumn{15}{|c|}{${ }^{2}$ Fisher's LSD test for prepartum to differ from 4 DIM. } \\
\hline \multirow{3}{*}{\multicolumn{15}{|c|}{$\begin{array}{l}{ }^{3} \text { Standard error of the mean }(\mathrm{n}=4 \text {; except for } 4 \text { DIM HMBi where } \mathrm{n}=3 \text { ). } \\
{ }^{4} \text { Fixed effects when prepartum observations are excluded from data set. } \\
{ }^{*} P 0.05 ;{ }^{*} P \leq 0.01 \text { (difference between means within DIM). }\end{array}$}} \\
\hline & & & & & & & & & & & & & & \\
\hline & & & & & & & & & & & & & & \\
\hline & & & & & & & & & & & & & & \\
\hline & & & & & & & & & & & & & & \\
\hline & & & & & & & & & & & & & & \\
\hline & & & & & & & & & & & & & & \\
\hline
\end{tabular}


Table 4. Net portal fluxes ${ }^{1}$ of AA in periparturient Holstein cows supplemented with 2-hydroxy-4-(methylthio)-butanoic acid isopropyl ester (HMBi; 1.5 g/kg of DM) or not supplemented (CON) from the day of parturition

\begin{tabular}{|c|c|c|c|c|c|c|c|c|c|c|c|c|c|c|}
\hline \multirow{2}{*}{$\begin{array}{l}\text { Plasma flux } \\
(\mathrm{mmol} / \mathrm{h})\end{array}$} & \multicolumn{2}{|c|}{ Prepartum } & \multirow[b]{2}{*}{$P_{\text {trans } \times \text { trt }}^{2}$} & \multirow[b]{2}{*}{$P_{\text {trans }}{ }^{3}$} & \multicolumn{2}{|c|}{$4 \mathrm{DIM}$} & \multicolumn{2}{|c|}{15 DIM } & \multicolumn{2}{|c|}{29 DIM } & \multirow[b]{2}{*}{$\mathrm{SEM}^{4}$} & \multicolumn{3}{|c|}{$P$-value ${ }^{5}$} \\
\hline & $\mathrm{CON}$ & HMBi & & & $\mathrm{CON}$ & HMBi & $\mathrm{CON}$ & HMBi & $\mathrm{CON}$ & $\mathrm{HMBi}$ & & Trt & DIM & Trt $\times$ DIM \\
\hline Essential AA & 72 & 81 & 0.52 & $<0.01$ & 128 & 150 & 156 & 145 & 193 & 182 & 9.70 & 0.82 & $<0.01$ & 0.29 \\
\hline Branched-chain AA & 31 & 38 & 0.73 & $<0.01$ & 64 & 74 & 81 & 72 & 97 & 87 & 4.20 & 0.42 & $<0.01$ & 0.10 \\
\hline His & 4.3 & 3.5 & 0.24 & 0.17 & 4.6 & 6.6 & 7.8 & 6.4 & 8 & 8 & 1.23 & 0.99 & 0.20 & 0.49 \\
\hline Ile & 9.3 & 11 & 0.75 & $<0.01$ & 19 & 22 & 22 & 21 & 28 & 26 & 1.63 & 0.85 & $<0.01$ & 0.44 \\
\hline Leu & 11 & 14 & 0.80 & $<0.01$ & 25 & 29 & 32 & 30 & 38 & 34 & 1.49 & 0.36 & $<0.01$ & 0.08 \\
\hline Lys & 15 & 16 & 0.94 & 0.02 & 20 & 22 & 25 & 24 & 32 & 31 & 2.39 & 0.85 & $<0.01$ & 0.86 \\
\hline Met & 3.6 & 4.3 & 0.60 & $<0.01$ & 6.2 & 7.5 & 7 & 6.8 & 9.0 & 9.5 & 0.58 & 0.50 & $<0.01$ & 0.48 \\
\hline Phe & 8.5 & 9.2 & 0.49 & $<0.01$ & 14 & 17 & 16 & 16 & 20 & 20 & 1.24 & 0.55 & $<0.01$ & 0.52 \\
\hline Thr & 8.5 & 8.6 & 0.35 & $<0.01$ & 16 & 19 & 16 & 17 & 22 & 22 & 2.18 & 0.75 & 0.04 & 0.80 \\
\hline Trp & 1.4 & 1.7 & 0.99 & 0.02 & 2.8 & 3.1 & 3.2 & 3.6 & 4.2 & 3.8 & 0.53 & 0.94 & 0.21 & 0.73 \\
\hline Val & 10 & 12 & 0.64 & $<0.01$ & 20 & 24 & 26 & 22 & 32 & 27 & 2.11 & 0.34 & 0.02 & 0.16 \\
\hline Nonessential AA & 51 & 75 & 0.59 & $<0.01$ & 138 & 135 & 183 & 126 & 223 & 185 & 20.6 & 0.03 & 0.02 & 0.57 \\
\hline Ala & 24 & 27 & 0.97 & $<0.01$ & 45 & 48 & 55 & 50 & 62 & 58 & 4.30 & 0.51 & 0.04 & 0.64 \\
\hline Asn & 8.4 & 11 & 0.91 & $<0.01$ & 16 & 18 & 20 & 17 & 21 & 21 & 2.20 & 0.76 & 0.20 & 0.51 \\
\hline Asp & 1.2 & 1.2 & 0.26 & 0.06 & 2.7 & 1.7 & 2.6 & 2.2 & 3.5 & 3.5 & 0.85 & 0.70 & 0.16 & 0.82 \\
\hline Cys & 2.8 & 1.7 & 0.62 & 0.45 & 3.6 & 5.0 & 1.5 & 3.5 & 2.7 & 0.6 & 1.30 & 0.72 & 0.18 & 0.30 \\
\hline Gln & -16 & -4.5 & 0.69 & 0.89 & -12 & -15 & -0.3 & -22 & 34 & -0.9 & 14.9 & 0.05 & 0.10 & 0.59 \\
\hline Glu & -1.7 & -1.2 & 0.92 & $<0.01$ & 2.4 & 2.7 & 4.1 & 3.1 & 5.0 & 4.9 & 0.99 & 0.73 & 0.10 & 0.81 \\
\hline Gly & 8.1 & 11 & 0.31 & 0.01 & 32 & 24 & 45 & $20^{* *}$ & 34 & 28 & 4.72 & $<0.01$ & 0.56 & 0.35 \\
\hline Pro & 4.2 & 5.6 & 0.64 & $<0.01$ & 11 & 11 & 14 & 13 & 17 & 15 & 1.37 & 0.37 & 0.01 & 0.88 \\
\hline Ser & 14 & 16 & 0.98 & $<0.01$ & 25 & 27 & 27 & 26 & 28 & 38 & 3.04 & 0.24 & 0.10 & 0.29 \\
\hline Tyr & 7.0 & 8.4 & 0.36 & $<0.01$ & 13 & 13 & 14 & 14 & 16 & 17 & 0.93 & 0.79 & 0.01 & 0.83 \\
\hline Total AA & 123 & 155 & 0.84 & $<0.01$ & 266 & 286 & 339 & 272 & 417 & 367 & 27.6 & 0.10 & $<0.01$ & 0.41 \\
\hline
\end{tabular}

${ }^{1}$ Net portal flux was calculated as portal blood plasma flow $\times$ (portal concentration - arterial concentration).

${ }^{2}$ Fisher's LSD test for treatment effect on difference between prepartum and 4 DIM.

${ }^{3}$ Fisher's LSD test for prepartum to differ from 4 DIM.

${ }^{4}$ Standard error of the mean $(\mathrm{n}=4$; except for 4 DIM HMBi where $\mathrm{n}=3)$.

${ }^{5}$ Fixed effects when prepartum observations are excluded from data set.

${ }^{*} P \leq 0.05 ;{ }^{*} P \leq 0.01$ (difference between means within DIM). 
Table 5. Net hepatic fluxes ${ }^{1}$ of AA in periparturient Holstein cows supplemented with 2-hydroxy-4-(methylthio)-butanoic acid isopropyl ester (HMBi; 1.5 g/kg of DM) or not supplemented $(\mathrm{CON})$ from the day of parturition

\begin{tabular}{|c|c|c|c|c|c|c|c|c|c|c|c|c|c|c|}
\hline \multirow{2}{*}{$\begin{array}{l}\text { Plasma flux } \\
(\mathrm{mmol} / \mathrm{h})\end{array}$} & \multicolumn{2}{|c|}{ Prepartum } & \multirow[b]{2}{*}{$P_{\text {trans } \times \operatorname{trt}^{2}}$} & \multirow[b]{2}{*}{$P_{\text {trans }}^{3}$} & \multicolumn{2}{|c|}{$4 \mathrm{DIM}$} & \multicolumn{2}{|c|}{15 DIM } & \multicolumn{2}{|c|}{29 DIM } & \multirow[b]{2}{*}{$\mathrm{SEM}^{4}$} & \multicolumn{3}{|c|}{$P$-value ${ }^{5}$} \\
\hline & $\mathrm{CON}$ & HMBi & & & $\mathrm{CON}$ & HMBi & $\mathrm{CON}$ & $\mathrm{HMBi}$ & $\mathrm{CON}$ & HMBi & & Trt & DIM & Trt $\times$ DIM \\
\hline Essential AA & -18 & -28 & 0.64 & 0.73 & -22 & -28 & -34 & -13 & -33 & -21 & 7.5 & 0.29 & 0.82 & 0.12 \\
\hline Branched-chain AA & 1.6 & -7.2 & 0.66 & 0.96 & -0.4 & -5.7 & -11 & 1.0 & -7.7 & 1.6 & 4.0 & 0.24 & 0.78 & 0.08 \\
\hline His & -1.9 & -2.3 & 0.87 & 0.92 & -2.0 & -1.9 & -3.9 & -1.9 & -1.2 & -3.2 & 1.6 & 0.88 & 0.91 & 0.58 \\
\hline Ile & 1.6 & -1.5 & 0.99 & 0.41 & 0.2 & -2.9 & -2.8 & 1.0 & -2.4 & 0.2 & 1.6 & 0.40 & 0.99 & 0.16 \\
\hline Leu & -0.5 & -1.8 & 0.48 & 0.51 & -0.6 & -0.2 & -4.7 & $0.1 * *$ & -4.0 & $1.6^{* *}$ & 1.0 & $<0.01$ & 0.23 & 0.04 \\
\hline Lys & -4.1 & -3.5 & 0.48 & 0.70 & -4.9 & -1.3 & -3.5 & -2.0 & -4.9 & 0.7 & 2.4 & 0.25 & 0.90 & 0.58 \\
\hline Met & -1.7 & -2.6 & 0.80 & 0.51 & -2.2 & -2.9 & -2.2 & -2.2 & -1.7 & -3.0 & 0.5 & 0.08 & 0.86 & 0.58 \\
\hline Phe & -6.3 & -6.9 & 0.65 & 0.85 & -6.1 & -7.6 & -7.6 & -5.6 & -8.6 & -9.5 & 0.9 & 0.95 & 0.03 & 0.32 \\
\hline Thr & -4.6 & -4.7 & 0.65 & 0.17 & -6.0 & -6.9 & -4.9 & -0.8 & -7.8 & -6.1 & 1.9 & 0.47 & 0.01 & 0.18 \\
\hline Trp & -0.8 & -1.1 & 0.94 & 0.82 & -0.8 & -1.3 & -1.6 & -1.2 & -1.4 & -1.2 & 0.6 & 0.94 & 0.80 & 0.80 \\
\hline Val & 0.6 & -3.9 & 0.80 & 0.99 & -0.04 & -3.5 & -3.0 & -0.1 & -1.2 & -0.1 & 2.7 & 0.95 & 0.86 & 0.18 \\
\hline Nonessential AA & -50 & -53 & 0.77 & 0.05 & -102 & -93 & -111 & -71 & -116 & -114 & 18.2 & 0.29 & 0.47 & 0.60 \\
\hline Ala & -22 & -23 & 0.21 & $<0.01$ & -48 & -57 & -48 & -42 & -45 & -49 & 3.9 & 0.74 & 0.14 & 0.08 \\
\hline Asn & -2.9 & -5.2 & 0.59 & $<0.01$ & -9.0 & -9.6 & -10 & -7.6 & -6.6 & -10.3 & 1.5 & 0.81 & 0.82 & 0.04 \\
\hline Asp & 0.5 & 0.7 & 0.81 & $<0.01$ & 1.9 & 2.3 & 0.8 & 1.2 & 1.1 & 0.1 & 0.5 & 0.68 & 0.06 & 0.32 \\
\hline Cys & -2.2 & -0.6 & 0.50 & 0.64 & -2.0 & -2.4 & -5.0 & -5.0 & -5.7 & -1.7 & 1.6 & 0.49 & 0.15 & 0.28 \\
\hline Gln & -1.8 & -4.3 & 0.25 & 0.18 & 1.2 & 34 & 4.5 & 19 & -2.9 & 0.4 & 15 & 0.34 & 0.60 & 0.72 \\
\hline Glu & 20 & 26 & 0.89 & $<0.01$ & 40 & 45 & 35 & 42 & 32 & 39 & 2.8 & 0.22 & 0.02 & 0.85 \\
\hline Gly & -21 & -22 & 0.43 & $<0.01$ & -63 & -72 & -53 & -45 & -53 & -45 & 5.9 & 0.52 & 0.04 & 0.33 \\
\hline $\begin{array}{l}\text { Pro } \\
\text { Pro }\end{array}$ & -1.9 & -3.0 & 0.63 & 0.37 & -2.5 & -5.0 & -5.6 & -6.4 & -4.8 & -6.2 & 1.4 & 0.10 & 0.35 & 0.86 \\
\hline Ser & -13 & -14 & 0.31 & 0.02 & -17 & -25 & -24 & -21 & -26 & -34 & 3.3 & 0.24 & 0.05 & 0.19 \\
\hline Tyr & -5.6 & -6.9 & 0.94 & 0.09 & -3.5 & -4.6 & -4.9 & -5.1 & -6.3 & -7.2 & 1.3 & 0.52 & 0.17 & 0.93 \\
\hline Total AA & -68 & -82 & 0.73 & 0.08 & -125 & -122 & -145 & -84 & -149 & -135 & 24 & 0.24 & 0.52 & 0.43 \\
\hline
\end{tabular}

¿ $\quad{ }^{1}$ Net hepatic flux was calculated as hepatic blood plasma flow $\times$ hepatic concentration - (portal plasma flow $\times$ portal concentration + hepatic arterial blood plasma flow $\times$ arterial concentration)

를 ${ }^{2}$ Fisher's LSD test for treatment effect on difference between prepartum and 4 DIM.

글 ${ }^{3}$ Fisher's LSD test for prepartum to differ from 4 DIM.

N Standard error of the mean $(\mathrm{n}=4$; except for 4 DIM HMBi where $\mathrm{n}=3$ ).

ऽ ${ }^{5}$ Fixed effects when prepartum observations are excluded from data set.

$\frac{\Omega}{\Phi}$. $\quad * * P \leq 0.01$ (difference between means within DIM) 
the greatest quantity by the liver; however, hepatic Glu release decreased from 4 to $29 \operatorname{DIM}(P=0.02)$.

\section{Net Splanchnic Fluxes}

The net splanchnic fluxes of total EAA and all individual EAA except for His increased $(P<0.01$ to $P=$ 0.03; Table 6) from prepartum to 4 DIM. Postpartum, the EAA was released by splanchnic tissues in increasing amounts as lactation progressed $(P<0.01$ to $P=$ $0.08)$ except for His $(P=0.43)$ and $\operatorname{Trp}(P=0.35)$, for which the flux did not change from 4 to 29 DIM in accordance with the patterns of the portal fluxes.

The net splanchnic fluxes of Asp, Glu, Pro, and Tyr increased $(P<0.01)$ from prepartum to 4 DIM. For Ala, a change $(P=0.05)$ was observed from net splanchnic release prepartum to net splanchnic uptake at 4 DIM. The net splanchnic uptake of Ala on 4 DIM was changed into net release by 15 and 29 DIM $(P=$ 0.02). For Cys, the opposite occurred from d 4 to 15 postpartum where the net splanchnic release changed into net uptake $(P=0.02)$. For Gly, the prepartum to 4 DIM difference in net splanchnic uptake was affected by treatment $(P<0.01)$, reflected by a sharper increase in the net splanchnic uptake in HMBi compared with control. Glycine was the only AA for which there was net splanchnic uptake at all 3 postpartum sampling days, and a treatment by DIM interaction $(P<0.01)$ was observed, reflecting an initially larger net splanchnic uptake in HMBi compared with control (4 and 15 DIM) and similar values for both treatments at 29 DIM. The net splanchnic release of Pro was decreased $(P=0.05)$ in HMBi compared with control and increased $(P=$ $0.05)$ for both treatments as lactation progressed.

\section{Milk Recovery of EAA}

The net portal and net splanchnic supply of EAA could not account for the EAA secreted in milk protein (Figure 1). Treatment did not affect $(P=0.81$; Figure 1a) EAA deficiency relative to the net portal flux of EAA. The EAA balance relative to the net portal flux increased from $-172 \pm 24 \mathrm{~g}$ of EAA to $+10 \pm 22 \mathrm{~g}$ of EAA between 4 and 29 DIM $(P<0.01$; Figure 1a). The EAA balance relative to the net splanchnic flux of EAA increased from $-248 \pm 18 \mathrm{~g}$ of EAA to $-74 \pm$ $18 \mathrm{~g}$ of EAA between 4 and 29 DIM $(P<0.01$; Figure $1 \mathrm{~b})$ and was not affected by treatment $(P=0.33)$. A total of $4,700 \pm 600 \mathrm{~g}$ of EAA from extra-splanchnic sources were secreted in milk protein during the first 29 DIM.

\section{DISCUSSION}

\section{Effects of HMBi Supplementation}

Methionine has been identified as the most often limiting AA in dairy cows (Schwab et al., 1992). Supplementation with ruminally protected Met (Bach et al., 2000; Berthiaume et al., 2006) and the Met analog HMBi (Graulet et al., 2005; St-Pierre and Sylvester, 2005) have proven efficacious to improve the Met status of dairy cows by increasing Met concentrations in blood plasma. This was also observed in the present study, where supplementation with $1.5 \mathrm{~g} / \mathrm{kg} \mathrm{DM}$ of HMBi increased arterial Met in postpartum transition dairy cows within $4 \mathrm{~d}$ of dietary inclusion. Contrary to the response to the supplementation of ruminally protected Met (Bach et al., 2000; Berthiaume et al., 2006), supplementation with HMBi did not increase the net portal flux or net splanchnic flux of Met. On the contrary, we observed a tendency toward an increased hepatic uptake of Met, indicating an apparent decrease in net splanchnic output of Met with HMBi. These effects of HMBi on Met status and metabolism are in line with the previously observed conversion of HMB to Met in extra splanchnic tissues of ruminants (Lobley et al., 2006; Wester et al., 2006). Supplementation with HMBi at parturition immediately affected arterial Met and prevented the decrease in the arterial Met concentration observed in the nonsupplemented cows. However, the Met response did not persist, as the arterial concentration of Met in HMBi-supplemented cows decreased with time and did not differ from control cows at 29 DIM. This suggests an adaptation of tissue Met metabolism to increased Met supply.

In a continuous study design, St-Pierre and Sylvester (2005) observed an immediate milk production response to supplementation of $1.5 \mathrm{~g}$ of $\mathrm{HMBi} / \mathrm{kg}$ of $\mathrm{DM}$ initiated at wk 4 of lactation, which persisted for the entire study of 16 wk. Several other studies have shown a response to HMBi on milk protein production (Phipps et al., 2008; Ordway et al., 2009). In the present study, the milk casein content in HMBi tended to decrease at a lower rate compared with control as lactation progressed. Previously, increased supply of metabolizable Met either from postruminal infusion (Pisulewski et al., 1996) or from HMBi supplementation (Rulquin et al., 2006) to cows in established lactation has increased the casein content without affecting the whey protein content of the milk.

A milk fat response to supplementary Met has been observed in numerous studies over a couple of decades (Polan et al., 1970; Emmanuel and Kennelly, 1984; 
Table 6. Net splanchnic ${ }^{1}$ fluxes of AA in periparturient Holstein cows supplemented with 2-hydroxy-4-(methylthio)-butanoic acid isopropyl ester (HMBi; 1.5 g/kg of DM) or not supplemented $(\mathrm{CON})$ from the day of parturition

\begin{tabular}{|c|c|c|c|c|c|c|c|c|c|c|c|c|c|c|}
\hline \multirow{2}{*}{$\begin{array}{l}\text { Plasma flux } \\
(\mathrm{mmol} / \mathrm{h})\end{array}$} & \multicolumn{2}{|c|}{ Prepartum } & \multirow[b]{2}{*}{$P_{\text {trans } \times \operatorname{trt}^{2}}{ }^{2}$} & \multirow[b]{2}{*}{$P_{\text {trans }}{ }^{3}$} & \multicolumn{2}{|c|}{4 DIM } & \multicolumn{2}{|c|}{15 DIM } & \multicolumn{2}{|c|}{29 DIM } & \multirow[b]{2}{*}{$\mathrm{SEM}^{4}$} & \multicolumn{3}{|c|}{$P$-value ${ }^{5}$} \\
\hline & $\mathrm{CON}$ & HMBi & & & $\mathrm{CON}$ & HMBi & $\mathrm{CON}$ & $\mathrm{HMBi}$ & $\mathrm{CON}$ & HMBi & & Trt & DIM & Trt $\times$ DIM \\
\hline Essential AA & 55 & 73 & 0.92 & $<0.01$ & 105 & 123 & 122 & 133 & 160 & 161 & 8.7 & 0.35 & $<0.01$ & 0.79 \\
\hline Branched-chain AA & 32 & 30 & 0.47 & $<0.01$ & 63 & 68 & 70 & 74 & 90 & 89 & 4.0 & 0.68 & $<0.01$ & 0.82 \\
\hline His & 2.5 & 1.2 & 0.37 & 0.33 & 2.6 & 5.0 & 3.9 & 4.5 & 6.8 & 4.8 & 1.8 & 0.93 & 0.43 & 0.63 \\
\hline Ile & 11 & 9.7 & 0.78 & $<0.01$ & 19 & 19 & 19 & 22 & 26 & 26 & 1.6 & 0.39 & $<0.01$ & 0.71 \\
\hline Leu & 11 & 13 & 0.53 & $<0.01$ & 25 & 29 & 28 & 30 & 34 & 36 & 1.6 & 0.10 & $<0.01$ & 0.89 \\
\hline Lys & 11 & 12 & 0.40 & 0.02 & 15 & 22 & 22 & 22 & 27 & 32 & 2.8 & 0.24 & 0.02 & 0.61 \\
\hline Met & 1.9 & 1.7 & 0.52 & $<0.01$ & 4.0 & 4.7 & 4.8 & 4.5 & 7.3 & 6.6 & 0.6 & 0.62 & $<0.01$ & 0.63 \\
\hline Phe & 2.2 & 2.3 & 0.71 & $<0.01$ & 7.8 & 8.5 & 8.3 & 10 & 12 & 11 & 0.8 & 0.63 & 0.01 & 0.14 \\
\hline Thr & 3.9 & 3.8 & 0.56 & $<0.01$ & 10 & 12 & 11 & 16 & 14 & 16 & 1.4 & 0.10 & 0.08 & 0.37 \\
\hline Trp & 0.7 & 0.5 & 0.92 & 0.03 & 2.0 & 1.7 & 1.6 & 2.4 & 2.8 & 2.6 & 0.5 & 0.89 & 0.35 & 0.52 \\
\hline Val & 11 & 8 & 0.52 & $<0.01$ & 20 & 20 & 23 & 22 & 30 & 27 & 1.9 & 0.45 & $<0.01$ & 0.58 \\
\hline Nonessential AA & 1.0 & 21 & 0.62 & 0.26 & 36 & 37 & 72 & 55 & 107 & 72 & 21 & 0.29 & 0.09 & 0.80 \\
\hline Ala & 1.3 & 3.2 & 0.31 & 0.05 & -3.3 & -8.8 & 7.9 & 7.1 & 17 & 9.2 & 4.3 & 0.35 & 0.02 & 0.71 \\
\hline Asn & 5.5 & 5.5 & 0.78 & 0.35 & 6.8 & 7.9 & 9.5 & 9.1 & 14 & 11 & 2.1 & 0.65 & 0.09 & 0.57 \\
\hline Asp & 1.7 & 1.9 & 0.22 & $<0.01$ & 4.6 & 4.3 & 3.4 & 3.5 & 4.6 & 3.6 & 0.7 & 0.62 & 0.02 & 0.21 \\
\hline Cys & 0.6 & 1.0 & 0.63 & 0.21 & 1.7 & 2.0 & -3.5 & -1.5 & -3.0 & -1.1 & 1.5 & 0.32 & 0.02 & 0.94 \\
\hline Gln & -18 & -8.8 & 0.59 & 0.34 & -11 & 18 & 4.3 & -2.7 & 31.5 & -0.4 & 18 & 0.61 & 0.59 & 0.39 \\
\hline Glu & 18 & 24 & 0.76 & $<0.01$ & 42 & 47 & 38.7 & 44.6 & 37.4 & 44 & 2.6 & 0.16 & 0.23 & 0.96 \\
\hline Gly & -13 & -12 & $<0.01$ & $<0.01$ & -31 & $-51^{* *}$ & -8.8 & $-25^{* *}$ & -19 & -18 & 3.5 & 0.06 & $<0.01$ & $<0.01$ \\
\hline Pro & 2.4 & 2.6 & 0.28 & $<0.01$ & 8.2 & 5.5 & 8.7 & 6.4 & 11.9 & 9.2 & 1.3 & 0.05 & 0.05 & 0.98 \\
\hline Ser & 0.9 & 1.6 & 0.20 & 0.12 & 7.6 & 2.5 & 3.0 & 5.1 & 2.4 & 4.1 & 2.0 & 0.83 & 0.59 & 0.18 \\
\hline Tyr & 1.4 & 1.5 & 0.61 & $<0.01$ & 9.3 & 8.3 & 9.4 & 8.9 & 10 & 10 & 1.2 & 0.67 & 0.57 & 0.90 \\
\hline Total AA & 55 & 73 & 0.92 & $<0.01$ & 141 & 161 & 194 & 188 & 267 & 233 & 28 & 0.59 & 0.02 & 0.76 \\
\hline
\end{tabular}

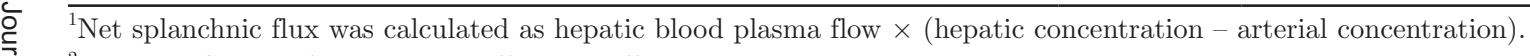

${ }^{2}$ Fisher's LSD test for treatment effect on difference between prepartum and 4 DIM.

을 $\quad{ }^{3}$ Fisher's LSD test for prepartum to differ from 4 DIM.

${ }^{4}$ Standard error of the mean $(\mathrm{n}=4$; except for 4 DIM HMBi where $\mathrm{n}=3)$.

₹. $\quad{ }^{5}$ Fixed effects when prepartum observations are excluded from data set.

œ $* * P \leq 0.01$ (difference between means within DIM). 


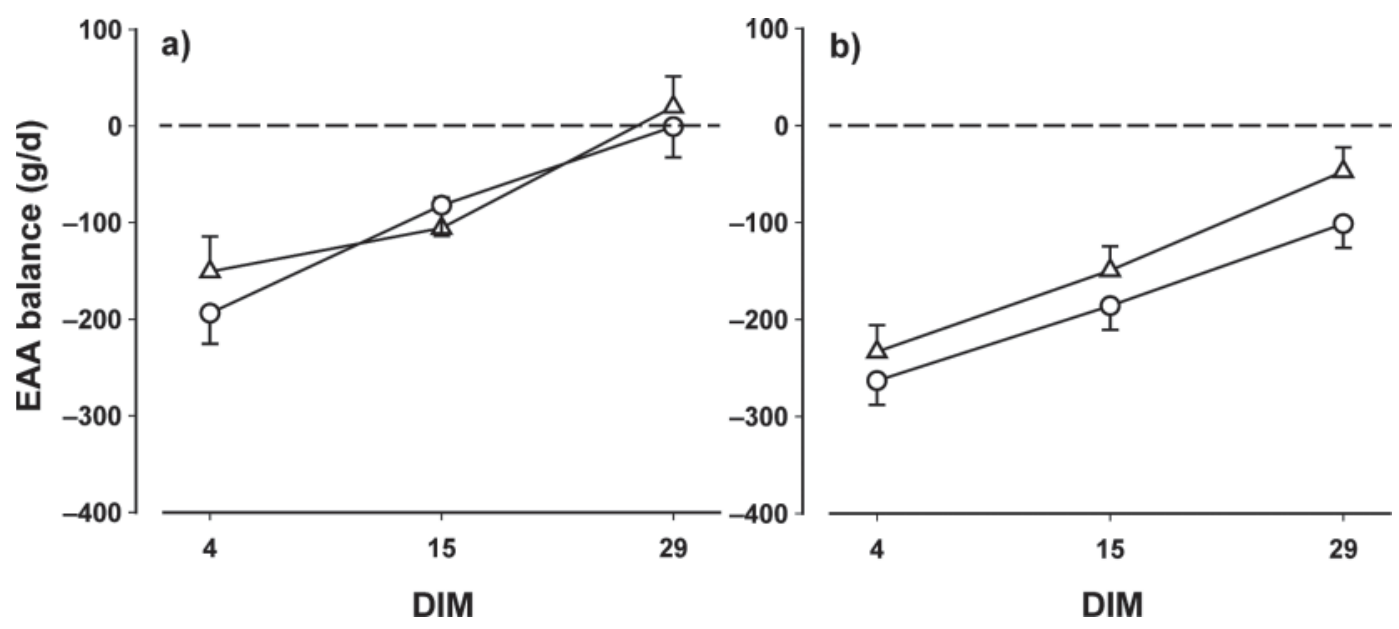

Figure 1. The deficiency in net portal flux (a) and net splanchnic flux (b) of essential AA (EAA) to account for milk secretion of EAA (g/d) in postpartum transition cows supplemented with the isopropyl ester of 2-hydroxy-4-(methylthio)-butanoic acid $(\Delta, \mathrm{HMBi})$ or unsupplemented $(\bigcirc$, control $)$ from the day of parturition. The deficiency relative to net portal flux was not affected by treatment $(P=0.81)$ and increased $(P<$ $0.01)$ from -172 to $+10 \mathrm{~g} / \mathrm{d}$ of EAA between 4 and 29 DIM. The deficiency relative to net splanchnic flux was not affected by treatment $(P=$ $0.33)$, and increased $(P<0.01)$ from -248 to $-74 \mathrm{~g} / \mathrm{d}$ of EAA between 4 and 29 DIM. Each data point is the mean of 4 observations \pm SEM (except 4 DIM HMBi, where $\mathrm{n}=3$ ).

Varvikko et al., 1999). However, the metabolic explanation for this response has not been finally settled and it is unclear why the milk fat response is inconsistent both among studies and Met sources (Phipps et al., 2008; Ordway et al., 2009; Patton, 2010). Stimulation of liver export of lipoproteins by Met supply has often been discussed; however, the hepatic export of triacylglycerol in lipoproteins is very sparse in ruminants compared with, for example, rats (Grummer, 1993) and it seems unlikely that Met supplementation has any major effects on liver lipoprotein export in dairy cows (McCarthy et al., 1968; Bertics and Grummer, 1999; Piepenbrink et al., 2004). Substantial amounts of phosphatidyl choline are secreted in milk fat globule membranes, where it accounts for approximately $30 \%$ of phospholipids (Kanno, 1990) and Met supply could replenish the methyl pool of the cow. However, as substantial remethylation of homocysteine takes place (Lobley et al., 1996) and the carbon sources for this remethylation are readily available in form of Ser and Gly (perhaps also His) it could be speculated that the depletion of Met postpartum limits transmethylation reactions because too little Met is available for S-adenosylmethionine synthesis despite plentiful availability of methyl sources. Plasma levels of Ser and Gly are increased postpartum and the cows seem therefore not depleted in sources for methyl groups for remethylation, but arterial concentrations of Gly, Ser, and His decreased with HMBi supplementation, which could indicate a larger pull on these AA as methyl donors with an increased Met status. This is further supported by increased hepatic extraction rates of Ser and His $(P<0.01$ and $P=0.07$; data not shown $)$ postpartum in HMBi compared with control indicating an active hepatic response to decreasing arterial concentrations.

The net splanchnic flux of Leu tended to be greater for HMBi, which was brought about by decreased liver extraction. This agrees with observations by Berthiaume et al. (2006) where increasing doses of rumenprotected Met increased the splanchnic flux of Leu as well as the other branched-chain AA. Branched-chain AA are generally catabolized to a smaller extent by the liver compared with other EAA (Reynolds, 2006). Decarboxylation of the branched chain $\alpha$-ketoacids by the branched chain $\alpha$-ketoacid dehydrogenase complex is the rate-limiting step in the catabolic pathway and is shared by all the branched chain $\alpha$-ketoacids but also the $\alpha$-ketobutyrate derived from methionine (Bequette et al., 1998). Interaction between the substrates is a possible explanation as to why the greater removal of Met affects the hepatic metabolism of Leu with HMBi.

The tendency for reduced concentration of His as a response to HMBi supplementation agrees with the previously proposed mechanism (Schwab et al., 1992) that enhanced Met status improves the utilization of other EAA, although we cannot distinguish the use of His in protein synthesis and catabolic reactions including methylation reactions.

Overall, HMBi appear to be a fast-acting source of metabolizable Met also in postpartum transition dairy cows and HMBi supplementation prevented a decrease in the arterial Met concentration observed in unsupplemented cows. 


\section{AA Balance of the Postpartum Transition Cow}

The transition from no milk protein production prepartum to $1.2 \mathrm{~kg}$ of protein/d within $4 \mathrm{~d}$ challenges the AA status of the cow. The EAA drainage by the mammary gland decreased the circulating levels of EAA in line with previous observations (Meijer et al., 1995; Larsen and Kristensen, 2009) on transition cows. Using indirect measures of changes in body composition, losses of body protein during early lactation are estimated to be $8 \mathrm{~kg}$ from $2 \mathrm{wk}$ prepartum to $8 \mathrm{wk}$ postpartum (Phillips et al., 2003) and $21 \mathrm{~kg}$ from 2 wk prepartum to $5 \mathrm{wk}$ postpartum (Komaragiri and Erdman, 1997). In a serial slaughter trial, Gibb et al. (1992) estimated the net whole-body protein loss to be $5.6 \mathrm{~kg}$ during the first $8 \mathrm{wk}$ of lactation.

It has been speculated that splanchnic tissues were responsible for the immediate supply of AA after parturition due to the high protein turnover in these tissues (Bell et al., 2000); however, the current study and the data from Larsen and Kristensen (2009) demonstrate that the crucial endogenous EAA supply were of extrasplanchnic origin. Also, previous protein depletion-repletion studies showed that skeletal muscles were by far the largest contributor to protein mobilization (Swick and Benevenga, 1977). Moreover, increasing abundance of mRNA coding for proteins in the ubiquitin-mediated proteolytic pathway in muscle biopsies from both postpartum transition cows and sows (Clowes et al., 2005; Chibisa et al., 2008) support that milk protein secretion in the initial phase of the lactation is largely sustained by protein mobilization from skeletal muscle. From the present data, a whole-body EAA mobilization can be estimated at 4,700 $\pm 600 \mathrm{~g}$ during the first $29 \mathrm{DIM}$ as a stepwise area under the curve estimation from the net splanchnic deficiency (Figure 1b).

Even though mobilization of protein in skeletal muscle is the largest endogenous source of AA in the early postpartum period, the immediate postpartum uterine involution might also be a quantitatively important AA source during the first days of lactation. The available pool of CP has been estimated to be between 1,100 g (Gibb et al., 1992) and 1,300 g (Andrew et al., 1994). Assuming $45 \%$ EAA in uterine protein, the cow will have from 500 to $600 \mathrm{~g}$ of EAA available from the uterus, and uterine EAA might be especially important in the first days of lactation due to an expected hyperbolic pattern of uterine involution (Hanigan et al., 2009).

\section{AA Sources for Mammary Protein Excretion}

Milk protein content decreases rapidly after calving to a minimum at 5 to $10 \mathrm{wk}$ in milk (Ng-Kwai-Hang et al., 1984), similar to the decrease from 4.2 to $3.0 \%$ observed in the present study. The concentration of both whey and casein in milk followed the same pattern as the total protein concentration. Further, the casein, whey, and NPN fractions were estimated to constitute approximately 80,16 , and $3 \%$, respectively, of total $\mathrm{N}$ in milk protein, and this distribution was unaffected by DIM. The caseins are exclusively synthesized from free AA in the mammary gland, whereas the whey fraction consists of both mammary-synthesized proteins $(\alpha-\mathrm{LA}$ and $\beta-\mathrm{LG})$ and proteins derived from the blood (e.g., immunoglobulins, serum albumin). The proteins derived from blood comprise a fraction of milk $\mathrm{N}$ not accounted for by the splanchnic release of EAA; however, the immunoglobulin levels in milk are expected to have been extensively reduced by 4 DIM (Levieux and Ollier, 1999; Madsen et al., 2004) and will therefore account for only a minor contribution to the 250 $\mathrm{g}$ of EAA in milk protein originating from endogenous sources. This corresponds to previous reported milk protein proportions (Cerbulis and Farrell, 1975) and demonstrates that the high milk protein concentration at 4 DIM is not only a result of immunoglobulin and plasma proteins transferred to the milk. The postpartum decrease in plasma protein content seems not to be related to a continuous transfer of quantitatively significant amounts of proteins or peptides from blood to milk. The present study does not allow for any assessment of an eventual net splanchnic flux of peptidebound AA taken up by the mammary gland, but as this pathway seems to be of limited quantitative importance (Backwell et al., 1996), we infer that both AA available from dietary sources and the AA mobilized are transported to the mammary gland as free AA and not as intact proteins from plasma.

\section{CONCLUSIONS}

The hydroxy analog of methionine 2-hydroxy4-(methylthio)-butanoic acid isopropyl ester (HMBi) is a fast-acting source of metabolizable Met in postpartum transition dairy cows. When HMBi was supplemented from the day of parturition, the arterial blood plasma concentration of Met increased for the first 4 DIM and hepatic uptake of Met tended to increase during the entire period of supplementation. Supplementation with HMBi tended to increase milk fat content and decrease plasma concentrations of Ser, Gly, and His, pointing toward increased methyl-group transfer activity in response to HMBi supplementation and increased Met status. Cows mobilized substantial amounts of EAA from extra-splanchnic tissues to sustain milk protein production for the first 29 DIM, and mobilization was not affected by HMBi supplementation. The relative contents of casein and whey fractions in milk protein 
were not affected by HMBi supplementation or DIM, and we infer that milk protein synthesis was sustained by free AA derived from uterine involution and mobilization from skeletal muscle.

\section{ACKNOWLEDGMENTS}

We gratefully acknowledge Birgit H. Løth, Anne Krustrup, Thorkild N. Jakobsen, Ole H. Olsen, and the barn staff at the Faculty of Agricultural Sciences, Aarhus University (Tjele, Denmark) for skillful technical assistance. MetaSmart was kindly provided for the study by Adisseo France S.A.S. (Antony, France). Funding for the present study was provided by the Directorate for Food, Fisheries and Agri Business (Copenhagen, Denmark; \#3304-VMP-05-005), The Danish Cattle Federation (Aarhus, Denmark), and Faculty of Agricultural Sciences, Aarhus University (Tjele, Denmark).

\section{REFERENCES}

Andrew, S. M., D. R. Waldo, and R. A. Erdman. 1994. Direct analysis of body composition of dairy cows at three physiological stages. J. Dairy Sci. 77:3022-3033.

Bach, A., G. B. Huntington, S. Calsamiglia, and M. D. Stern. 2000. Nitrogen metabolism of early lactation cows fed diets with two different levels of protein and different amino acid profiles. J. Dairy Sci. 83:2585-2595

Backwell, F. R. C., B. J. Bequette, D. Wilson, J. A. Metcalf, M. F, Franklin, D. E. Beever, G. E. Lobley, and J. C. MacRae. 1996. Evidence for the utilization of peptides for milk protein synthesis in the lactating dairy goat in vivo. Am. J. Physiol. 271:R955-R960.

Bell, A. W., W. S. Burhans, and T. R. Overton. 2000. Protein nutrition in late pregnancy, maternal protein reserves and lactation performance in dairy cows. Proc. Nutr. Soc. 59:119-126.

Bequette, B. J., F. R. C. Backwell, and L. A. Crompton. 1998. Current concepts of amino acid and protein metabolism in the mammary gland of the lactating ruminant. J. Dairy Sci. 81:2540-2559.

Berthiaume, R., M. C. Thivierge, R. A. Patton, P. Dubreuil, M. Stevenson, B. W. McBride, and H. Lapierre. 2006. Effect of ruminally protected methionine on splanchnic metabolism of amino acids in lactating dairy cows. J. Dairy Sci. 89:1621-1634.

Bertics, S. J., and R. R. Grummer. 1999. Effects of fat and methionine hydroxy analog on prevention or alleviation of fatty liver induced by feed restriction. J. Dairy Sci. 82:2731-2736.

Calder, A. G., K. E. Garden, S. E. Anderson, and G. E. Lobley. 1999. Quantitation of blood and plasma amino acids using isotope dilution electron impact gas chromatography/mass spectrometry with $\mathrm{U}-{ }^{13} \mathrm{C}$ amino acids as internal standards. Rapid Commun. Mass Spectrom. 13:2080-2083.

Cerbulis, J., and H. M. Farrell Jr. 1975. Composition of milks of dairy cattle. I. Protein, lactose, and fat contents and distribution of protein fraction. J. Dairy Sci. 58:817-827.

Chibisa, G. E., G. N. Gozho, A. G. Van Kessel, A. A. Olkowski, and T. Mutsvangwa. 2008. Effects of peripartum propylene glycol supplementation on nitrogen metabolism, body composition, and gene expression for the major protein degradation pathways in skeletal muscle in dairy cows. J. Dairy Sci. 91:3512-3527.

Clowes, E. J., F. X. Aherne, and V. E. Baracos. 2005. Skeletal muscle protein mobilization during the progression of lactation. Am. J. Physiol. Endocrinol. Metab. 288:E564-E572.

DePeters, E. J., and J. P. Cant. 1992. Nutritional factors influencing the nitrogen composition of bovine milk: A review. J. Dairy Sci. $75: 2043-2070$
Drackley, J. K. 1999. Biology of dairy cows during the transition period: The final frontier. J. Dairy Sci. 82:2259-2273.

Emmanuel, B., and J. J. Kennelly. 1984. Kinetics of methionine and choline and their incorporation into plasma lipids and milk components in lactating goats. J. Dairy Sci. 67:1912-1918.

Gibb, M. J., W. E. Ivings, M. S. Dhanoa, and J. D. Sutton. 1992. Changes in body components of autumn-calving Holstein-Friesian cows over the 1st 29 weeks of lactation. Anim. Prod. 55:339-360.

Graulet, B., C. Richard, and J. C. Robert. 2005. Methionine availability in plasma of dairy cows supplemented with methionine hydroxy analog isopropyl ester. J. Dairy Sci. 88:3640-3649.

Grummer, R. R. 1993. Etiology of lipid-related metabolic disorders in periparturient dairy cows. J. Dairy Sci. 76:3882-3896.

Grummer, R. R. 1995. Impact of changes in organic nutrient metabolism on feeding the transition dairy cow. J. Anim. Sci. 73:2820 2833.

Hanigan, M. D., C. C. Palliser, and P. Gregorini. 2009. Altering the representation of hormones and adding consideration of gestational metabolism in a metabolic cow model reduced prediction errors. J. Dairy Sci. 92:5043-5056.

Harvey, R. B., and A. J. Brothers. 1962. Renal extraction of para-aminohippurate and creatine measured by continuous in vivo sampling of arterial and renal-vein blood. Ann. N. Y. Acad. Sci. 102:46-54

Kanno, C. 1990. Secretory membranes of the lactating mammary gland. Protoplasma 159:184-208.

Komaragiri, M. V. S., and R. A. Erdman. 1997. Factors affecting body tissue mobilization in early lactation dairy cows. 1. Effect of dietary protein on mobilization of body fat and protein. J. Dairy Sci. 80:929-937.

Kristensen, N. B., B. A. Røjen, B. M. L. Raun, A. C. Storm, L. Puggard, and M. Larsen. 2009. Hepatic acetylation of the blood flow marker $p$-aminohippuric acid affect measurement of hepatic blood flow in cattle. Pages 558-559 in Ruminant Physiology: Digestion, Metabolism, and Effects of Nutrition on Reproduction and Welfare. Y. Chilliard, F. Glasser, Y. Fauconnier, F. Bocquier, I. Veissier, and M. Doreau, ed. Wageningen Academic Publishers, Wageningen, the Netherlands.

Kristensen, N. B., A. Storm, B. M. L. Raun, B. A. Rojen, and D. L. Harmon. 2007. Metabolism of silage alcohols in lactating dairy cows. J. Dairy Sci. 90:1364-1377.

Larsen, M., and N. B. Kristensen. 2009. Effect of abomasal glucose infusion on splanchnic amino acid metabolism in periparturient dairy cows. J. Dairy Sci. 92:3306-3318.

Levieux, D., and A. Ollier. 1999. Bovine immunoglobulin G, betalactoglobulin, alpha-lactalbumin and serum albumin in colostrum and milk during the early post partum period. J. Dairy Res. $66: 421-430$.

Lobley, G. E., A. Connell, and D. Revell. 1996. The importance of transmethylation reactions to methionine metabolism in sheep: Effects of supplementation with creatine and choline. Br. J. Nutr. $75: 47-56$.

Lobley, G. E., T. J. Wester, A. G. Calder, D. S. Parker, J. J. Dibner, and M. Vázquez-Añón. 2006. Absorption of 2-hydroxy-4-methylthiobutyrate and conversion to methionine in lambs. J. Dairy Sci. 89:1072-1080.

Madsen, B. D., M. D. Rasmussen, M. O. Nielsen, L. Wiking, and L. B. Larsen. 2004. Physical properties of mammary secretions in relation to chemical changes during transition from colostrum to milk. J. Dairy Res. 71:263-272.

McCarthy, R. D., G. A. Porter, and L. C. Griel Jr.. 1968. Bovine ketosis and depressed fat test in milk: a problem of methionine metabolism and serum lipoprotein aberration. J. Dairy Sci. 51:459-462.

Meijer, G. A. L., J. Van der Meulen, J. G. M. Bakker, C. J. Van der Koelen, and A. M. Van Vuuren. 1995. Free amino acids in plasma and muscle of high yielding dairy cows in early lactation. J. Dairy Sci. 78:1131-1141.

Ng-Kwai-Hang, K. F., J. F. Hayes, J. E. Moxley, and H. G. Monardes. 1984. Variability of test-day milk production and composition and relation of somatic cell counts with yield and compositional changes of bovine milk. J. Dairy Sci. 67:361-366. 
Ordway, R. S., S. E. Boucher, N. L. Whitehouse, C. G. Schwab, and B. K. Sloan. 2009. Effects of providing two forms of supplemental methionine to periparturient Holstein dairy cows on feed intake and lactational performance. J. Dairy Sci. 92:5154-5166.

Patton, R. A. 2010. Effect of rumen-protected methionine on feed intake, milk production, true milk protein content, and true milk protein yield, and the factors that influence these effects: A metaanalysis. J. Dairy Sci. 93:2105-2118.

Phillips, G. J., T. L. Citron, J. S. Sage, K. A. Cummins, M. J. Cecava, and J. P. McNamara. 2003. Adaptations in body muscle and fat in transition dairy cattle fed differing amounts of protein and methionine hydroxy analog. J. Dairy Sci. 86:3634-3647.

Phipps, R. H., C. K. Reynolds, D. I. Givens, A. K. Jones, P. A. Geraert, E. Devillard, and R. Bennett. 2008. Short communication: Effects of 2-hydroxy-4-(methylthio) butanoic acid isopropyl ester on milk production and composition of lactating Holstein dairy cows. J. Dairy Sci. 91:4002-4005.

Piepenbrink, M. S., A. L. Marr, M. R. Waldron, W. R. Butler, T. R. Overton, M. Vazquez-Anon, and M. D. Holt. 2004. Feeding 2-hydroxy-4-(methylthio)-butanoic acid to periparturient dairy cows improves milk production but not hepatic metabolism. J. Dairy Sci. 87:1071-1084.

Pisulewski, P. M., H. Rulquin, J. L. Peyraud, and R. Verite. 1996. Lactational and systemic responses of dairy cows to postruminal infusions of increasing amounts of methionine. J. Dairy Sci. 79:1781-1791.

Polan, C. E., P. T. Chandler, and C. N. Miller. 1970. Methionine hydroxy analog: Varying levels for lactating cows. J. Dairy Sci. 53:607-610.

Reynolds, C. K. 2006. Splanchnic amino acid metabolism in ruminants. Pages 225-248 in Ruminant Physiology: Digestion, Metabolism and Impact of Nutrition on Gene Expression, Immunology and Stress. K. Sejrsen, T. Hvelplund, and M. O. Nielsen, ed. Wageningen Academic Publishers, Wageningen, the Netherlands.
Rulquin, H., B. Graulet, L. Delaby, and J. C. Robert. 2006. Effect of different forms of methionine on lactational performance of dairy cows. J. Dairy Sci. 89:4387-4394.

Schwab, C. G., C. K. Bozak, N. L. Whitehouse, and M. M. A. Mesbah. 1992. Amino acid limitation and flow to duodenum at four stages of lactation. 1. Sequence of lysine and methionine limitation. J. Dairy Sci. 75:3486-3502.

Sjaunja, L. O., L. Baevre, L. Junkkarinen, J. Pedersen, and J. Setälä. 1991. A Nordic proposal for an energy corrected milk (ECM). Pages 156-157 in Proc. 27th Session of International Committee for Recording Productivity of Milk Animals (ICRPMA). Eur. Assoc. Anim. Prod. Publ. No 50. Eur. Assoc. Anim. Prod., Wageningen, the Netherlands.

St-Pierre, N. R., and J. T. Sylvester. 2005. Effects of 2-hydroxy4-(methylthio) butanoic acid (HMB) and its isopropyl ester on milk production and composition by Holstein cows. J. Dairy Sci. 88:2487-2497.

Swaisgood, H. E. 1995. Protein and amino acid composition of bovine milk. Pages 464-468 in Handbook of Milk Composition. R. G. Jensen, ed. Academic Press, Toronto, Ontario, Canada.

Swick, R. W., and N. J. Benevenga. 1977. Labile protein reserves and protein turnover. J. Dairy Sci. 60:505-515.

Varvikko, T., A. Vanhatalo, T. Jalava, and P. Huhtanen. 1999. Lactation and metabolic responses to graded abomasal doses of methionine and lysine in cows fed grass silage diets. J. Dairy Sci. 82:2659-2673.

Volden, H., ed. 2011. NorFor-The Nordic Feed Evaluation System. EAAP Publication No. 130. Wageningen Academic Publishers, Wageningen, the Netherlands.

Wester, T. J., M. Vazquez-Anon, J. Dibner, D. S. Parker, A. G. Calder, and G. E. Lobley. 2006. Hepatic metabolism of 2-hydroxy-4-methylthiobutyrate in growing lambs. J. Dairy Sci. 89:1062-1071. 